\title{
Penerapan Metode Simple Additive Weighting Dalam Pemberian Dana Bantuan Pemerintah Kota Pada Lingkungan XI Daerah Kwala Bekala
}

\author{
Tesa Aurelia Siregar, Nola Dita Puspa, Dwika Assrani \\ Program Studi Teknik Informatika, Universitas Budi Darma, Medan, Indonesia

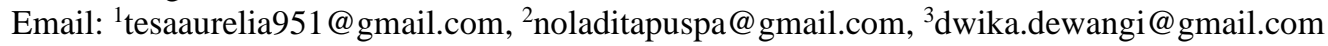

\begin{abstract}
Abstrak-Bantuan pemerintah kota di berikan pemerintah kepada orang yang salah sering terjadi, pihak pembenyalur bantuan hanya memberi kepada kerabat terdekat saja bukan orang yang benar-benar membutuhkan, terjadinya kesenjangan sosial. Tidak meratanya pembagian sembako ini diakibatkan kurang telitinya pemerintah dalam mengumpulkan data-data warga yang kurang mampu dan warga yang terkena PHK dan penutupan akses berdagang ketika pandemi Covid-19 membuat ekonomi masyarakat sangat merosot drastis. Dari masalah tersebut dibutuhkan sistem pendukung keputusan untuk membantu pihak penyalur bantuan menyeleksi orang yang berhak diberikan bantuan dengan pendekatan metode Simple Additive Weighting (SAW) dan hasil keputusan ini akan akan diperoleh 1-15 kadidat yang benar-benar pantas untuk mendapatkan bantuan pemerintah kota dan mengurangi kecurangan dalam pemberian bantuan pada masa Pandemi Covid-19.
\end{abstract}

Kata Kunci: Dana Bantuan; Sistem Pendukung Keputusan, Simple Additive Weighting, Metode SAW

Abstract-City government assistance given by the government to the wrong people often occurs, the aid distributor only gives to the closest relatives, not people who really need it, social inequality occurs. The uneven distribution of basic needs is due to the government's inaccuracy in collecting data on underprivileged citizens and residents who have been laid off and closing access to trade when the Covid-19 pandemic has made the community's economy slump drastically. From this problem, a decision support system is needed to help aid distributors select people who are entitled to be given assistance with the Simple Additive Weighting (SAW) method approach and the results of this decision will be obtained from 1-15 candidates who really deserve to get city government assistance and reduce fraud in providing assistance during the Covid-19 Pandemic.

Keywords: Aid Fund; Decision Support System, Simple Additive Weighting, SAW Method

\section{PENDAHULUAN}

Munculnya virus yang bernama covid-19. Virus ini berasal dari kota Huan yang ada di China. Virus ini sudah menyebar luas diseluruh dunia termasuk Indonesia. Covid-19 merupakan wabah penyakit yang merusak sistem pernapasan hingga mengakibatkan kematian, maka dari itu, pemerintah mengeluarkan peraturan seperti menggunakan masker, selalu cuci tangan, jauhi keramaian, dan tetap di rumah saja jika tidak ada keperluan di luar, terjadinya covid-19 ini dikarenakan kurang kesadaran setiap manusia untuk menjaga kebersihan[1]. Covid-19 juga mengakibatkan perekonomian Indonesia menurun drastis dan jumlah pengangguran semakin bertambah, maka dari itu pemerintah mengambil kebijakan untuk memulihkan keadaan dengan cara memberikan bantuan yang berupa sembako.

Salah satu bantuan yang diberikan oleh pemerintah kota berupa bantuan sembako, dikarenakan bantuan pemerintah kota merupakan pemberian dari pemerintah untuk orang yang tidak mampu dan pemberian sembako untuk warga yang terkena Pemutusan Hubungan Kerja (PHK) ketika Pandemi Covid-19. Bantuan pemerintah kota juga merupakan bantuan yang sangat dibutuhkan oleh masyarakat pada masa covid-19 yang akan diberikan kepada masyarakat dengan beberapa kriteria sebagai syarat penerima bantuan[2].

Adapun kriteria jenis bantuan dari pemerintah kota yaitu surat keterangan miskin, wajib terdaftar pada kartu keluarga (KK) Lingkungan 11 Kwala Bekala, tidak bekerja, dan gaji kurang 3.200.000 atau gaji dibawah Upah Minimum Kota (UMK) daerah setempat. Kriteria jenis bantuan merupakan suatu syarat dari pemerintah untuk memberikan bantuan kepada warga. Setiap warga harus wajib memenuhi kriteria sebagai syarat mendapatkan bantuan pemerintah kota dari pemerintah dan pemerintah pun juga harus adil dalam memberikan bantuan pemerintah kota tersebut dikarenakan setiap warga sangat membutuhkan dan mengharapkan bantuan tersebut.

Namun ada beberapa warga yang tidak menerima bantuan tersebut, padahal merekalah yang sangat membutuhkan bantuan tersebut. Tidak meratanya pembagian sembako ini diakibatkan dari kurangnya teliti Pemerintah setempat dalam mengumpulkan data-data warga yang kurang mampu dan warga yang terkena PHK ketika Pandemi Covid-19. Dibeberapa daerah lain yang terkena dampak dari Pandemi Covid-19 ini tidak merata nya pembagian, lalu salah nya sasaran, dan ada pihak lain yang mengambil keuntungan untuk pribadinya sendiri. Sehingga, banyaknya warga yang tidak dapat atau pun tidak sesuai sembako yang didapat dari Pemerintah Pusat.

Ketika warga melapor ke Pihak yang terkait dalam menanganin Bantuan Pemerintah kota, warga tersebut tidak mendapatkan respon apa pun itu tidak ada kejelasan dari pihak mereka, malahan mereka melempar masalah 
ini ke Kepala Lingkungan daerah masing-masing. Padahal warga tersebut mendapat arahan dari Kepala Lingkungan tersebut untuk melapor ke Pemerintah setempat yang menanganin Bantuan Sembako tidak mungkin warga tersebut melapor ke Pemerintah Pusat tanpa adanya pengarahan.

Dari masalah tersebut, seharusnya Pemerintah Pusat lebih jeli lagi dalam penanganan kasus tersebut apalagi kasus itu sangat dirasakan oleh warga yang terkena Dampak Pandemi Covid-19. Kasus tersebut sangat merugikan warga yang sama sekali tidak mendapat gaji diakhir bulan ini. Warga sangat mengharapkan adanya solusi dari Pemerintah Pusat untuk kasus ini, agar Bantuan Sembako dibagikan secara merata atau bersikap adil. Pemerintah Pusat harusnya bisa terjun ke lapangan langsung untuk mengecek kondisi warga yang terkena Pandemi Covid-19 terutama Faktor Ekonomi warga tersebut. Tidak berjalan roda kehidupan ini tanpa adanya Faktor Ekonomi, maka warga sangat membutuhkan nilai dari ekonomi itu sendiri. Seharusnya Pemerinta lebih selektif lagi dalam menanganin kasus itu, karena ini sangatlah penting untuk kehidupan warga tersebut. Diharapkan Pemeritah Pusat atau yang berwewenang menangani kasus ini agar lebih peka terhadap keluhan warga.

Dari permasalahan di atas diperlukan sistem pendukung keputusan untuk membantu pemerintah kota dalam pemberian bantuan agar lebih selektif lagi dalam memilih dan menyaring warga yang berhak medapatkan bantuan tersebut, dengan sistem pendukung keputusan pengambilan keputusan terhadap warga yang akan diberi bantuan akan lebih adil dan tersistematis berdasarkan kriteria yang dimasukan kedalam sistem pendukung dan diproses dengan cepat berdasarkan sistem komputerisasi. Sistem pendukung keputusan sistem yang berbasis komputer yang menerapan metode-metode dalam penganalisaan data[3], [4]. Beberapa metode yang umum digunakan diantaranya metode Weighted Product (WP), Simple Additive Weighting (SAW). ELECTRE, MOORA, WASPAS. Beberapa penelitian yang dilakukan oleh peneliti terdahulu terkait dengan penerapan metode sistem pendukung keputusan diantaranya yang dilakukan oleh Iman Judi Situmeang pada tahun 2021 dengan penerapan metode Simple Additive Weighting (SAW) dapat menentukan duta kampus baik perwakilan dari mahasiswa dan mahasiswi[5]. Peneliti lainnya yaitu Nelly Khairani Daula di tahun 2021 melakukan komparasi terhadap metode WASPAS dan MOORA dalam menentukan penerima bantuan uang kuliah tunggal yang diberikan kepada mahasiswa yang terdampak Covid-19 [6], Nelly Khairani ditahun yang sama juga melakukan penelitian untuk meningkatkan efektifitas dalam pengambilan keputusan hubungan kerja terhadap karyawan dengan menggunakan metode WASPAS [7]. Pada tahun 2021 Rahma Yuni juga menggunakan metode SAW untuk pengambilan keputusan terhadap penerima bantuan terdampak Covid-19 [8].

Dari penjelasan di atas, pada penelitian ini penulis bertujuan untuk melakukan penelitian pada pemerintah kota dengan menggunakan metode Simple Additive Weighting) (SAW) dalam pemberian keputusan penerima bantuan sembako. Diharapkan dari penelitian ini dapat memberikan informasi yang objektif dan rentan dari kesalahan sehingga bantuan sembako yang diberikan dapat tepat sasaran.

\section{METODOLOGI PENELITIAN}

\subsection{Tahapan Penelitian}

Dalam penelitian ini penulis melakukan beberapa tahapan untuk menghasilkan informasi yang dibutuhkan, diantaranya:

a. Pengumpulan Data

Pada pengumpulan data penulis mengambil beberapa data dari pemerintah kota yang dijadikan rujukan dalam penerima bantuan sembako.

b. Studi Literatur

Pada tahapan ini penulis melakukan telaah terhadap literatur yang mendukung terlaksananya penelitian, seperti mengumpulkan penelitian-penelitian yang terkait dengan topik penelitian ini.

c. Analisa Masalah

Masalah yang diteliti terkait penerima bantuan sembako yang diberikan oleh pemerintah kota

d. Penerapan Metode Simple Additive Weighting (SAW)

Pada bagian ini penulis menggunakan metode SAW dalam pemeringkatan terhadap penerima yang layak mendapatkan bantuan sembako dari pemerintah kota.

e. Pengambilan Kesimpulan

Hasil akhir dari penelitian ini, penulis menyimpulkan kesimpulan akhir terkait penelitian yang dilakukan.

\subsection{Sistem Pendukung Keputusan}

Sistem pendukung keputusan merupakan suatu sistem yang digunakan untuk memudahkan menemukan keputusan dengan menggunakan sistem yang dirancang berdasarkan kriteria dan alternatif yang sudah di tentukan sebelumnya, sistem pendukung keputusan juga bertujuan untuk menyediakan informasi, membimbing, memberikan prediksi serta mengarahkan kepada pengguna informasi agar dapat melakukan pengambilan keputusan dan mendaptkan suatu informasi dengan baik[3], [9]-[11].

\subsection{Metode Simple Additive Weighting (SAW)}


SAW merupakan suatu metode yang dapat membantu dalam pengambilan sebuah keputusan pada suatu kasus tersebut. Metode ini juga terkenal dengan penjumlahan terbobot dari rating kinerja pada setiap altenatif pada semua atribut. Metode SAW membutuhkan waktu dalam perhitungan yang singkat. Adapun tahapan dari penerapan metode SAW[12]-[16], yaitu:

1. Menetapkan matriks keputusan (Xij)

2. Menghitung matriks ternormalisasi (Rij)

3. Menghitung nilai Preferensi (Vi)

\section{HASIL DAN PEMBAHASAN}

Dalam analisa ini peneliti menggunakan sistem pendukung keputusan yang akurat, dan dapat dipercaya dalam mempertimbangkan untuk mengambil sebuah keputusan pemberian bantuan pemerintah kota kepada masyarakat Lingkungan 11 Kwala Bekala dengan menggunakan metode SAW (Simple Additive Weighting).

\subsection{Penetapan Kriteria, Bobot dan Alternatif}

Berikut data kriteria yang terlihat pada tabel 1 dan data alternatif yang terlihat pada tabel 2, di bawah ini.

Tabel 1. Kriteria dan bobot

\begin{tabular}{clcc}
\hline Kriteria & \multicolumn{1}{c}{ Nama } & Keterangan & Bobot \\
\hline C1 & Surat keterangan Miskin & Benefit & 0.521 \\
C2 & Wajib Terdaftar Kk Lingkungan 11 Kwala Bekala & Benefit & 0.270 \\
C3 & Status Kerja & Cost & 0.146 \\
C4 & Gaji $<3.200 .000$ & Cost & 0.063 \\
\hline
\end{tabular}

Dari keterangan yang terdapat pada tabel 1 di atas, maka berikut ini penjelasan dari kriteria yang di harapkan untuk mengambil sebuah keputusan penentuan pemberian bantuan pemerintah kota Lingkungan 11 Kwala Bekala dengan menggunakan metode SAW (Simple Additive Weighting) sebagai berikut:

1. Surat Keterangan Miskin

Surat keterangan miskin merupakan surat yang hanya dimiliki oleh warga yang bener-bener miskin. Dan warga tersebut harus di utamakan dalam pembagian sembako pada Lingkungan $11 \mathrm{Kwala}$ Bekala karena mereka sangatlah membutuhkan bantuan pemerintah kota tersebut.

2. Wajib Terdaftar pada KK Lingkungan $11 \mathrm{Kwala}$ Bekala

Warga yang mendapatkan bantuan pemerintah kota harus wajib Kk nya terdaftar pada Lingkungan 11 Kwala Bekala.Jika tidak terdaftar Kk nya pada Lingkungan $11 \mathrm{Kwala}$ Bekala maka warga tersebut tidak mendapatkan bantuan pemerintah kota tersebut.

3. Status Kerja

Status kerja merupakan suatu kedudukan seseorang didalam pekerjaan tersebut. Tetapi, dimasa Covid-19 ini banyak seseorang yang di berhentikan paksa, maka terjadinya pengangguran semakin bertambah.

4. Gaji <3.200.000

Warga yang mendapatkan gaji yang dibawah dari 3.200.000 lah yang pantas untuk mendapatkan bantuan pemerintah kota pada Lingkungan 11 Kwala Bekala. Karna warga tersebut sangat mengharapkan bantuan tersebut.

Tabel 2. Nama Alternatif

\begin{tabular}{cl}
\hline Kode & Nama Alternatif \\
\hline A1 & Suhendra \\
A2 & Herbert Sihotang \\
A3 & Idrus Sagala \\
A4 & Atin \\
A5 & Maslan Sembiring \\
A6 & Agus Siswanto \\
A7 & Wirma Wati \\
A8 & Deni Boy \\
A9 & Suyanto \\
A10 & Anwar \\
A11 & M Safri \\
A12 & Ahmad Dibri \\
A13 & Januar Tamzil \\
A14 & Eri Edy \\
A15 & Awaluddin
\end{tabular}




\begin{tabular}{ll} 
A16 & Agdin Naibaho \\
A17 & Elon Kencana \\
A18 & Fran Irwanto Sihotang \\
A19 & Bambang Dedy Kurniawan \\
A20 & Asdyana Br Ginting \\
\hline
\end{tabular}

Pada tabel 3 berikut merupakan data nilai alternatif pada tiap tiap kriteria.

Tabel 3. Data dan Kriteria Alternatif

\begin{tabular}{lllcc}
\hline \multicolumn{1}{c}{ Alternatif } & \multicolumn{1}{c}{$\mathrm{C}_{1}$} & \multicolumn{1}{c}{$\mathrm{C}_{2}$} & $\mathrm{C}_{3}$ & $\mathrm{C}_{4}$ \\
\hline Suhendra (A1) & Ada & Terdaftar & Dirumahkan & 2.575 .000 \\
Herbert Sihotang (A2) & Ada & Terdaftar & Bekerja & 3.505 .000 \\
Idrus Sagala (A3) & Ada & Terdaftar & Dirumahkan & 1.950 .000 \\
Atin (A4) & Tidak & Terdaftar & Dirumahkan & 2.005 .000 \\
Maslan Sembiring (A5) & Tidak & Terdaftar & Bekerja & 3.750 .000 \\
Agus Siswanto (A6) & Ada & Tidak & Dirumahkan & 1.550 .000 \\
Wirma Wati (A7) & Ada & Terdaftar & Dirumahkan & 1.850 .000 \\
Deni Boy & Tidak & Tidak & Bekerja & 2.205 .000 \\
Suyanto (A9) & Ada & Tidak & Bekerja & 2.350 .000 \\
Anwar (A10) & Ada & Tidak & Dirumahkan & 1.800 .000 \\
M Safri (A11) & Tidak & Tidak & Bekerja & 1.950 .000 \\
Ahmad Dibri (A12) & Tidak & Terdaftar & Dirumahkan & 2.000 .000 \\
Januar Tamzil (A13) & Tidak & Terdaftar & Dirumahkan & 1.500 .000 \\
Eri Edy (A14) & Tidak & Terdaftar & Bekerja & 2.250 .000 \\
Awaluddin (A15) & Tidak & Terdaftar & Dirumahkan & 1.650 .000 \\
Agdin Naibaho (A16) & Tidak & Tidak & Bekerja & 2.250 .000 \\
Elon Kencana (A17) & Ada & Tidak & Dirumahkan & 1.705 .000 \\
Fran Irwanto Sihotang (A18) & Ada & Terdaftar & Dirumahkan & 1.500 .000 \\
Bambang Dedy Kurniawan (A19) & Ada & Tidak & Bekerja & 2.175 .000 \\
Asdyana Br Ginting (A20) & Ada & Tidak & Dirumahkan & 1.550 .000 \\
\hline
\end{tabular}

Pada data di atas terdapat data yang sifatnya linguistik sehingga harus dilakukan pembobotan terhadap data tersebut. Berikut tabel 4 untuk pembobotan terhadap data yang terdapat pada alternatif di setiap kriteria.

Tabel 4. Data dan Kriteria Alternatif

\begin{tabular}{lcc}
\hline \multicolumn{1}{c}{ Kriteria } & Keterangan & Nilai \\
\hline Surat Keterangan Miskin $\left(\mathrm{C}_{1}\right)$ & Ada & 2 \\
& Tidak & 1 \\
\hline Wajib Terdaftar Kk Lingkungan 11 Kwala Bekala $\left(\mathrm{C}_{2}\right)$ & Tidak & 1 \\
& Terdaftar & 2 \\
\hline Status Kerja $(\mathrm{C} 3)$ & Bekerja & 2 \\
& Dirumahkan & 1 \\
\hline
\end{tabular}

Sehingga berdasarkan pada tabel 4, maka data rating yang telah di bobotkan dapat terlihat pada tabel 5 berikut ini.

Tabel 5. Rating Kecocokan

\begin{tabular}{ccccc}
\hline Alternatif & $\mathrm{C}_{1}$ & $\mathrm{C}_{2}$ & $\mathrm{C}_{3}$ & $\mathrm{C}_{4}$ \\
\hline $\mathrm{A} 1$ & 2 & 2 & 1 & 2.575 .000 \\
$\mathrm{~A} 2$ & 2 & 2 & 2 & 3.505 .000 \\
$\mathrm{~A} 3$ & 2 & 2 & 1 & 1.950 .000 \\
$\mathrm{~A} 4$ & 1 & 2 & 1 & 2.005 .000 \\
$\mathrm{~A} 5$ & 1 & 2 & 2 & 3.750 .000 \\
$\mathrm{~A} 6$ & 2 & 1 & 1 & 1.550 .000 \\
$\mathrm{~A} 7$ & 2 & 2 & 1 & 1.850 .000 \\
$\mathrm{~A} 8$ & 1 & 1 & 2 & 2.205 .000 \\
$\mathrm{~A} 9$ & 2 & 1 & 2 & 2.350 .000 \\
$\mathrm{~A} 10$ & 2 & 1 & 1 & 1.800 .000 \\
$\mathrm{~A} 11$ & 1 & 1 & 2 & 1.950 .000 \\
$\mathrm{~A} 12$ & 1 & 2 & 1 & 2.000 .000 \\
$\mathrm{~A} 13$ & 1 & 2 & 1 & 1.500 .000 \\
$\mathrm{~A} 14$ & 1 & 2 & 2 & 2.250 .000
\end{tabular}




\begin{tabular}{lllll}
$\mathrm{A} 15$ & 1 & 2 & 1 & 1.650 .000 \\
$\mathrm{~A} 16$ & 1 & 1 & 2 & 2.250 .000 \\
$\mathrm{~A} 17$ & 2 & 1 & 1 & 1.705 .000 \\
$\mathrm{~A} 18$ & 2 & 2 & 1 & 1.500 .000 \\
$\mathrm{~A} 19$ & 2 & 1 & 2 & 2.175 .000 \\
$\mathrm{~A} 20$ & 2 & 1 & 1 & 1.550 .000 \\
\hline
\end{tabular}

\subsection{Penerapan Metode Simple Additive Weighting (SAW)}

Setelah data rating kecocokan diperoleh maka tahapan selanjutnya menggunakan metode SAW untuk melakukan pemeringkatan terhadap penduduk yang layak mendapatkan bantuan sembako dari pemerintah kota. Berikut tahapan dalam penerapan metode SAW.

Tahap 1: Menetapkan matrik keputusan (Xij) yang terlihat di bawah ini.

$$
\mathrm{Xij}=\left|\begin{array}{rrrr}
2 & 2 & 1 & 2.575 .000 \\
2 & 2 & 2 & 3.505 .000 \\
2 & 2 & 1 & 1.950 .000 \\
1 & 2 & 1 & 2.005 .000 \\
1 & 2 & 2 & 3.750 .000 \\
2 & 1 & 1 & 1.550 .000 \\
2 & 2 & 1 & 1.850 .000 \\
1 & 1 & 2 & 2.205 .000 \\
2 & 1 & 2 & 2.350 .000 \\
2 & 1 & 1 & 1.800 .000 \\
1 & 1 & 2 & 1.950 .000 \\
1 & 2 & 1 & 2.000 .000 \\
1 & 2 & 1 & 1.500 .000 \\
1 & 2 & 2 & 2.250 .000 \\
1 & 2 & 1 & 1.650 .000 \\
1 & 1 & 2 & 2.250 .000 \\
2 & 1 & 1 & 1.705 .000 \\
2 & 2 & 1 & 1.500 .000 \\
2 & 1 & 2 & 2.175 .000 \\
2 & 1 & 1 & 1.550 .000
\end{array}\right|
$$

Tahap 2: Menghitung matrik ternormalisasi.

Untuk jenis kriteria benefit maka digunakan persamaan ke 1, sedangkan untuk jenis kriteria cost digunakan persamaan ke 2 .

$$
\begin{aligned}
& r_{i j}=\frac{x_{i j}}{\max _{i} x_{i j}} \\
& r_{i j}=\frac{\min _{i} x_{i j}}{x_{i j}}
\end{aligned}
$$

Hasil dari perhitungan matrik ternormalisasi, diperoleh matrik Rij sebagai berikut.

$\mathrm{Rij}=\left|\begin{array}{llll}1.0000 & 1.0000 & 1.0000 & 0.5825 \\ 1.0000 & 1.0000 & 0.5000 & 0.4280 \\ 1.0000 & 1.0000 & 1.0000 & 0.7692 \\ 0.5000 & 1.0000 & 1.0000 & 0.7481 \\ 0.5000 & 1.0000 & 0.5000 & 0.4000 \\ 1.0000 & 0.5000 & 1.0000 & 0.9677 \\ 1.0000 & 1.0000 & 1.0000 & 0.8108 \\ 0.5000 & 0.5000 & 0.5000 & 0.6803 \\ 1.0000 & 0.5000 & 0.5000 & 0.6383 \\ 1.0000 & 0.5000 & 1.0000 & 0.8333 \\ 0.5000 & 0.5000 & 0.5000 & 0.7692 \\ 0.5000 & 1.0000 & 1.0000 & 0.7500 \\ 0.5000 & 1.0000 & 1.0000 & 1.0000 \\ 0.5000 & 1.0000 & 0.5000 & 0.6667 \\ 0.5000 & 1.0000 & 1.0000 & 0.9091\end{array}\right|$




\begin{tabular}{|llll}
0.5000 & 0.5000 & 0.5000 & 0.6667 \\
1.0000 & 0.5000 & 1.0000 & 0.8798 \\
1.0000 & 1.0000 & 1.0000 & 1.0000 \\
1.0000 & 0.5000 & 0.5000 & 0.6897 \\
1.0000 & 0.5000 & 1.0000 & 0.9677
\end{tabular} \mid

Tahap 3: Tahap akhir melakukan perhitungan untuk mendapat nilai preferensi (Vi) dengan menggunakan persamaan ke 3 berikut ini.

$$
v_{i}=\sum_{j=1}^{n} w_{j} r_{i j}
$$

Hasil perhitungan mendapatkan nilai rangking yang terlihat pada tabel 6 sebagai berikut.

Tabel 6. Rangking Alternatif

\begin{tabular}{lcc}
\hline \multicolumn{1}{c}{ Alternatif } & Nilai Vi & Rangking \\
\hline Fran Irwanto Sihotang (A18) & 1 & 1 \\
Wirma Wati (A7) & 0.9881 & 2 \\
Idrus Sagala (A3) & 0.9855 & 3 \\
Suhendra (A1) & 0.9737 & 4 \\
Herbert Sihotang (A2) & 0.891 & 5 \\
Agus Siswanto (A6) & 0.863 & 6 \\
Asdyana Br Ginting (A20) & 0.863 & 6 \\
Elon Kencana (A17) & 0.8574 & 7 \\
Anwar (A10) & 0.8545 & 8 \\
Bambang Dedy Kurniawan (A19) & 0.7724 & 9 \\
Suyanto (A9) & 0.7692 & 10 \\
Januar Tamzil (A13) & 0.7395 & 11 \\
Awaluddin (A15) & 0.7338 & 12 \\
Ahmad Dibri (A12) & 0.7238 & 13 \\
Atin (A4) & 0.7236 & 14 \\
Eri Edy (A14) & 0.6455 & 15 \\
Maslan Sembiring (A5) & 0.6287 & 16 \\
M Safri (A11) & 0.517 & 17 \\
Deni Boy (A8) & 0.5114 & 18 \\
Agdin Naibaho (A16) & 0.5105 & 19 \\
\hline
\end{tabular}

Pada tabel 6 terlihat bahwa alternatif A18 atas nama Fran Irwanto Sihotang, merupakan tertinggi dengan nilai 1. Pada hasil tabel 6 dapat di rekomendasikan sebanyak 1-15 calon penerima bantuan pemerintah kota.

\section{KESIMPULAN}

Berdasarkan penjabaran penelitian dapat disimpulkan bahwa bantuan pemerintah kota merupakan pemberian dari pemerintah untuk masyarakat yang membutuhkannya pada masa Covid-19. Sistem putusan tersebut menggunakan metode Saw, dan dari beberapa kandidat yang memiliki nilai tertinggi merupakan warga yang menerima bantuan pemerintah kota pada Lingkungan $11 \mathrm{Kwala}$ Bekala pada kandidat A18 yang mendapatkan rangking tertinggi. Dengan menggunakan sistem pendukung keputusan setiap keputusanan pemerintah diambil secara mutlak, adil dan tersistem berdasarkan hasil nilai yng dimiliki oleh tiap alternatif.

\section{REFERENCES}

[1] J. Kirana, K. P. Rajagukguk, E. Lailan, and S. Lubis, "ANALISIS DAMPAK COVID-19 PADA MASYARAKAT," vol. 1, pp. 64-69, 2020.

[2] L. R. Muaja et al., "Pada Pemerintah Daerah Kota Manado," Maret, vol. 2, no. 1, pp. 510-520, 2014.

[3] T. Limbong, "Implementasi Metode Simple Additive Weighting Untuk," Pengetahuan, J. Ilmu Komputer, D A N Teknol., vol. 3, no. 2, pp. 233-238, 2018.

[4] D. Nofriansyah, Multi Criteria Decision Making. Yogyakarta: Deepublish, 2017.

[5] I. J. T. Situmeang, S. Hummairoh, S. M. Harahap, and Mesran, "Application of SAW ( Simple Additive Weighting ) for the Selection of Campus Ambassadors," IJICS (International J. Informatics Comput. Sci., vol. 5, no. 1, pp. 21-28, 2021.

[6] N. K. Daulay, B. Intan, and M. Irvai, "Comparison of the WASPAS and MOORA Methods in Providing Single Tuition Scholarships," IJICS (International J. Informatics Comput. Sci., vol. 5, no. 1, pp. 84-94, 
2021.

[7] N. K. Daulay, "Penarapan Metode Waspas Untuk Efektifitas Pengambilan Keputusan Pemutusan Hubungan Kerja," J. Sist. Komput. dan Inform., vol. 2, no. 2, pp. 196-201, 2021.

[8] R. Y. Simanullang, Melisa, and Mesran, "Sistem Pendukung Keputusan Penerima Bantuan Covid-19 Menggunakan Metode Simple Additive Weighting (SAW)," TIN Terap. Inform. Nusant., vol. 1, no. 9, pp. 2-9, 2021.

[9] S. Kusumadewi, S. Hartati, A. Harjoko, and Retantyo Wardoyo, Fuzzy Multi-Attribute Decision Making (FUZZY MADM). 2006.

[10] E. Turban, J. E. Aronson, and T. Liang, "Decision Support Systems and Intelligent Systems."

[11] D. Nofriansyah, Konsep Data Mining Vs Sistem Pendukung Keputusan. 2015.

[12] S. K. Simanullang and A. G. Simorangkir, "Sistem Pendukung Keputusan Penerimaan Calon Karyawan Menggunakan Metode Simple Additive Weighting," TIN Terap. Inform. Nusant., vol. 1, no. 9, pp. 472478, 2021.

[13] M. R. Ramadhan, M. K. Nizam, and Mesran, "Penerapan Metode SAW (Simple Additive Weighting) Dalam Pemilihan Siswa-Siswi Berprestasi Pada Sekolah SMK Swasta Mustafa," TIN Terap. Inform. Nusant., vol. 1, no. 9, pp. 459-471, 2021.

[14] R. P. Sari and B. Saputra, "Sistem Pemilihan Smartphone Berdasarkan Spesifikasinya Pada Mahasiswa Sistem Informasi Universitas Tanjungpura Menggunakan Metode Simple Additive Weighting ( SAW )," J. Sist. Komput. dan Inform., vol. 2, no. 3, pp. 329-338, 2021.

[15] R. P. Sari and F. S. Redha, "Sistem Pendukung Keputusan Pemilihan Pemilihan Distro Linux Menggunakan metode Simple Additive Weighting (SAW)," J. Sist. Komput. dan Inform., vol. 2, no. 3, p. 88, 2021.

[16] S. H. Sahir, R. Rosmawati, and K. Minan, "Simple Additive Weighting Method to Determining Employee Salary Increase Rate,” Int. J. Sci. Res. Sci. Technol., vol. 3, no. 8, pp. 42-48, 2017. 